\title{
Robert Rogaczewski*
}

\section{FOREGIN DIRECT INVESTMENTS OF POLISH ENTERPRISES IN THE FEDERAL REPUBLIC OF GERMANY}

\begin{abstract}
A b s t r a c t: Foreign direct investments are one of the forms of internationalization of Polish enterprises. The purpose of this article is to analyze the FDI of Polish enterprises in the Federal Republic of Germany. The article presents the following research hypothesis: the increase in the value of particular characteristics (sales revenue, expenditure on fixed assets, employment rate, value of export and import) will affect the increase in the number of foreign entities. Based on statistical data from the Statistics Poland concerning business activities of Polish enterprises and their foreign subsidiaries in Germany a correlation coefficient was calculated. A positive correlation value means that the increase in the value of individual characteristics will affect the number of foreign units.
\end{abstract}

K e y w o r d s: foreign direct investment; Germany; internationalization.

J E L C o d e: L 21; N10

\section{INTRODUCTION}

Polish companies, due to the need of extending their customer portfolio and extending the scale of operations, as well as the barriers which they encounter on the domestic market, make decisions to expand into foreign markets. Apart from the aforementioned reasons, an important factor may be political stability and presence in the EU. Polish companies predominantly make foreign direct investments in Europe, mostly in Poland's neighboring countries. One of the important markets on which Polish companies are active is the Federal Republic of Germany. Usually, Polish companies acquire majority share packages or set up new companies or manufacturing plants.

\footnotetext{
* Contact information: Robert Rogaczewski, Państwowa Wyższa Szkoła Zawodowa w Koninie, Wydział Nauk Ekonomicznych i Technicznych, Katedra Nauk Ekonomicznych, ul. Przyjaźni 1, 62-510 Konin, email: r.rogaczewski@gmail.com
} 
The aim of this paper is to conduct a FDI analysis of Polish companies in Germany, pointing to the most important factors which instigate foreign activity of Polish companies. Due to the above, the following research hypothesis has been put forward: an increase in the value of individual characteristics (sales revenue, expenses on fixed assets, size of employment, value of imports and exports) will have an impact on an increase in the number of foreign entities. In order to verify the abovementioned research hypothesis, an analysis of the activity of Polish companies and their foreign entities in Germany, based on statistical data acquired from the Central Statistical Office.

\section{FOREIGN DIRECT INVESTMENTS AS A FORM OF COMPANIES' FOREIGN ACTIVITY}

As a rule, foreign direct investments should be perceived as companies' foreign expansion and can be analyzed on two levels. The first one involves setting up a completely new company abroad. Investments of this type are referred to in subject literature as greenfield. The second one, on the other hand, involves investors taking actions aimed at taking over an existing company by purchasing a package of shares sufficient for exercising full control over it. Such investments are called brownfield (Rymarczyk, 2012, p. 30).

Foreign direct investments are the most advanced form of companies' internationalization. According to Gabler Economic Lexicon, this type of investments are export of capital by economic entities of one country into another, with the aim of establishing manufacturing plants or subsidiaries, acquiring foreign companies or a participation of a company which will ensure significant impact on the company's policy (Alisch, Winter, Arentzen, 2004, p. 716). According to this definition, foreign direct investments are investments in all types of companies which operate in a different national economy.

Foreign direct investments are also understood as making investments in a country different than the one of investor's origin. The investments involve location of capital for a long-term period in a foreign company and gaining specific profit from it (Kuźmińska, Mirecka, Szeląg, 2010, p. 110).

Direct investments include, in particular, the establishment of new branches abroad, production plants or subsidiaries, joint ventures, the purchase of shares in existing companies, equipping a company with fixed assets and granting credit to companies abroad. (Czech-Winkelmann, Kopsch, 2008, p. 220).

The advantages and disadvantages of the hierarchy- and capital-based form of foreign direct investment should be indicated. The most important benefits of creating branches or subsidiaries or production and trade or manufacturing plants include the possibility of achieving profits of scale and location through the allocation and concentration of individual links in the value creation chain, 
a high degree of control over the activities of foreign subsidiaries, the possibility of reducing transport costs, bypassing customs barriers and other import restrictions or access to natural resources and cheap labor. In the case of defects, special attention should be paid to the complex process of managing the company and having sufficient financial and human resources necessary to establish a subsidiary or branch office. (Barłożewski, 2017). Foreign activity also involves high costs and non-financial barriers, such as risks of political, economic, market and cultural nature.

\section{FEDERAL REPUBLIC OF GERMANY AS A FIELD OF INVESTMENT FOR POLISH COMPANIES}

FDI of Polish companies are growing every year. At the end of 2017, according to the data published by the National Bank of Poland, Polish foreign direct investments reached the amount of 10.4 billion PLN, with the value of transactions with shares and other forms of capital stake amounting to 3.1 billion PLN (www.nbp.pl, 29.01.2019).

The fact that the cooperation and trade exchange between Germany and Poland is running smoothly is beyond doubt, which is confirmed by the size of that trade exchange.

Due to the geographic location of Germany and Poland and their pursuit of common interests, there is a growth tendency in international cooperation. Bilateral economic cooperation between Poland and Germany has been developing dynamically since the first decade of the 21 st century. The cooperation reached its peak at the moment of Poland's accession into the European Union. The EU expansion of 2004 served as a significant impulse for intensified trade exchange with Germany (Rogaczewski 2017, p. 93).

It is worth noting the trade turnover between Poland and Germany in 20002013. From the Polish perspective, they look as follows (Table 1):

Table 1. Trade turnover between Poland and Germany in 2000-2013 according to Central Statistical Office

\begin{tabular}{|c|c|c|c|}
\hline \multirow{2}{*}{ Year } & Import DE -> PL & Export PL > DE & Balance \\
\cline { 2 - 4 } & \multicolumn{3}{|c|}{ in mln EUR } \\
\hline 2000 & 12690 & 11978 & -712 \\
\hline 2001 & 13427 & 13819 & 393 \\
\hline 2002 & 14220 & 14070 & -150 \\
\hline 2003 & 14721 & 15351 & 629 \\
\hline 2004 & 17397 & 17909 & 512 \\
\hline 2005 & 20024 & 20142 & 118 \\
\hline
\end{tabular}




\begin{tabular}{|c|c|c|c|}
\hline 2006 & 24202 & 23870 & -332 \\
\hline 2007 & 28948 & 26370 & -2578 \\
\hline 2008 & 32755 & 29124 & -3631 \\
\hline 2009 & 24053 & 25686 & 1632 \\
\hline 2010 & 29362 & 31427 & 2065 \\
\hline 2011 & 34042 & 35664 & 1622 \\
\hline 2012 & 32836 & 36057 & 3221 \\
\hline 2013 & 34006 & 38888 & 4882 \\
\hline
\end{tabular}

Source: Wyżnikiewicz, B. (2014). Polish-German economic cooperation. Warsaw: Institute of Studies on Market Economy.

Those values are presented differently by the German Statistical Office. An interesting factor are the discrepancies between the Polish and German values related to foreign trade. The asymmetry is presented below (Graph 1):

Figure 1. Discrepancies in the Polish-German international trade

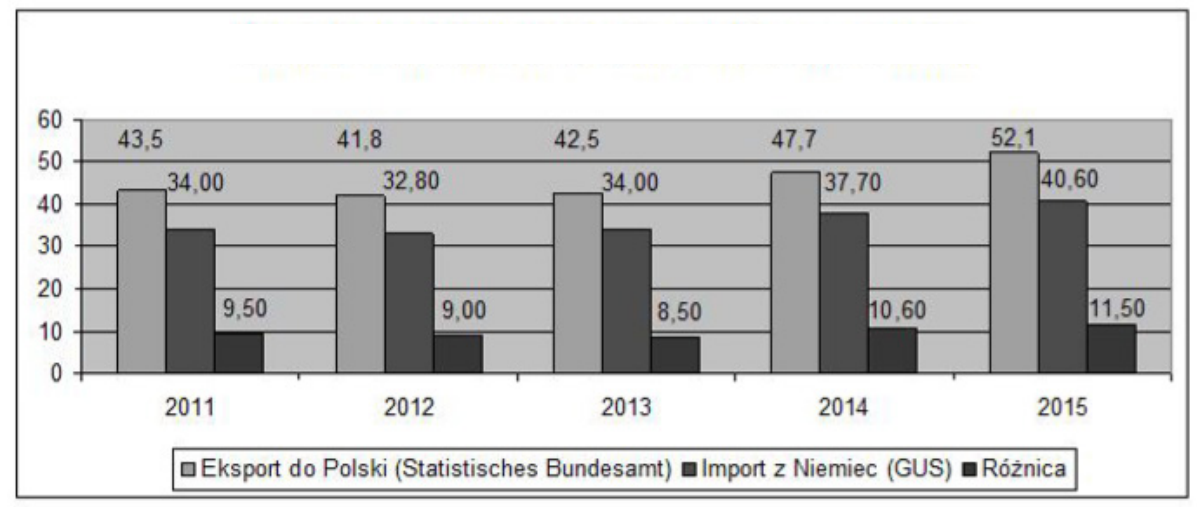

Source: own study based on Statistisches Bundesamt and Central Statistical Office data (Department of Information).

It results predominantly from a different manner of defining trade turnover. From the German perspective, it concerns the country from which the goods were shipped, whereas the Polish one takes into account the goods' country of origin (Wyżnikiewicz, 2014, p. 9).

Globalization and internationalization of the world economy is one of the key issues of interest, not only for governments, but above all for companies. Foreign expansion of companies is mainly due to the fact that domestic markets "press" companies to start looking for new markets. Such incentives are created primarily by increasing demand from foreign markets, in particular from rapidly 
developing countries. (KfW Bankengruppe, 2011, p.7). It should also include the expectations related to increased activity, the prospect of gaining profit and securing one's position on the market and the competitive ability. A company, due to taking appropriate precautions, can acquire technological, organizational and marketing advantage over its rivals.

In industrialized countries, foreign investments are treated on a par with domestic investment. There are no special restrictions, other than those arising from national security.

Germany is quite an important investment area for Polish companies, which become owners of German enterprises or acquire majority shareholdings in them. The motives behind the foreign expansion of Polish companies are also important. Usually, these are fiscal tools, such as tax or customs reliefs, the possibility of writing off losses from future income or reducing insurance premiums. Financial mechanisms are especially used in eastern Germany, where a mass movement of people to the west of Germany is observed. It follows that, despite the reunification of Germany, there is a significant difference in the size of salaries. In order to encourage foreign activities Individual regions in Germany offer, for example, sale of buildings at a reduced price, government loan guarantees, subsidized loan interest rates, etc.

It is worth pointing to the research conducted by Polish-German Chamber of Industry and Trade (AHK) entitled "Polskie przedsiębiorstwa w Niemczech: perspektywy działalności w Niemczech są jednoznacznie dobre" (Polish companies in Germany: prospects for activity in Germany are unequivocally positive" (AHK 2018). The research indicates that $100 \%$ of Polish companies which are active on the German market recommend this market as a direction of foreign expansion and, in case of having to choose again, would also decide on this investment place. The main factors in deciding on the expansion of Polish companies to Germany are primarily the acquisition of new markets and customers and the expansion of activities. Polish companies also appreciate the good quality of the infrastructure and the discipline in the area of business payments. The greatest difficulties on the German market are caused by the amount of tax burden, labor costs as well as availability of personnel (AHK 2018).

It is also worth noting other research conducted, among others, by the Bank of Poland "Germany in the opinion of Polish companies behind the Oder". (Bank of Poland, AHK, CMS 2016, p. 40). Their main objective was to assess the German economic situation and the conditions for doing business. In the assessment of companies (Figure 2), the main reason for the expansion was the desire to gain access to new markets and customers (about $79 \%$ of the respondents), or the need to increase the scale of operations or to meet a development barrier on the domestic market. 
Figure 2. Reasons for expansion into the German market

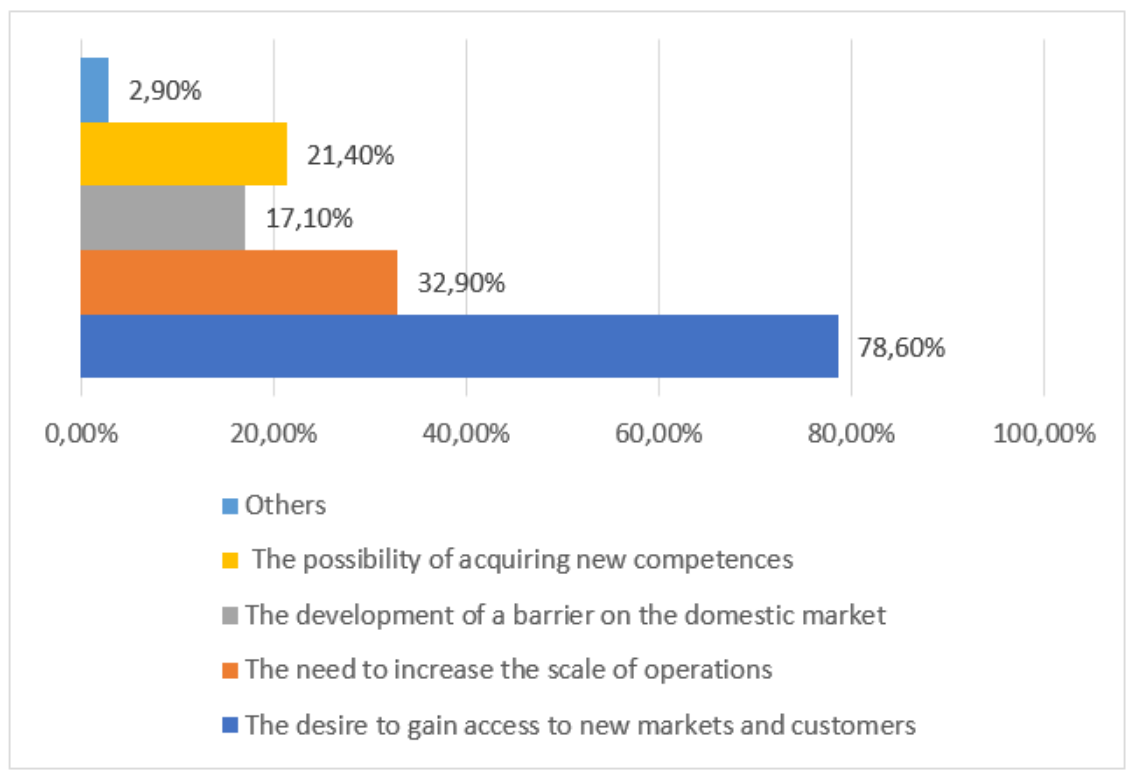

Source: (Bank of Poland, AHK, CMS, 2016)

Some of the companies which have taken over the companies in Germany through a buyout should be mentioned. Among others, the chemical company CIECH, which took over Sodawerke Straßfurtin 2007, or the furniture company Nowy Styl, which took over Rohde \& Grahl are worth mentioning here.

Some of the major companies which have their foreign branches in Germany are (Table 2):

Table 2. Selected Polish investments in Germany in 2012 (in millions Euro)

\begin{tabular}{|l|l|c|c|}
\hline \multicolumn{1}{|c|}{ Company } & \multicolumn{1}{c|}{ Subsidiary } & Assets & Turnover \\
\hline PKN Orlen & Orlen Deutschland GmbH & 396,9 & $3.949,1$ \\
\hline Comarch & Comarch AG & 51,6 & 28,2 \\
\hline Grupa Azoty & ATT Polymers GmbH & 36,3 & 106,6 \\
\hline Amica Wronki & Amica International & 12,4 & 71,0 \\
\hline Projprzem & Promstahl GmbH & 3,1 & 12,9 \\
\hline
\end{tabular}

Source: www.gtai.de, 30.01.2019

Orlen has been present on the German market since 2003. PKN Orlen company owns $100 \%$ of shares in Orlen Deutschland GmbH subsidiary, located in Elmshorn. The company deals with asset management and retail sales of fuels. 
The German market is recognized as the largest and most developed fuel market in Europe (www.orlen-deutschland.de, 07.10.2018). The main competitors of the Polish company in Germany are networks of international fuel stations, such as: Aral, Shell, Esso, Total (they account for $45 \%$ of the total number of petrol stations in Germany) and Jet and HEM economy networks (they account for less than $9 \%$ of the total petrol stations). In Germany, Orlen petrol stations operate under the name "Star" (Table 3).

Table 3. Employment structure in PKN Orlen companies

\begin{tabular}{|l|c|c|c|}
\hline & 2015 & 2016 & 2017 \\
\hline Orlen company & 19.931 & 19.730 & 20.262 \\
\hline Orlen Deutschland GmbH & 140 & 146 & 155 \\
\hline
\end{tabular}

Źródło: www.orlen.pl, 15.09.2018

In 2015, 140 foreign units were located in Germany. In 2017, the number of foreign units increased by almost $11 \%$.

Comarch is another example of a brownfield company from the IT industry based in Krakow. Sales offices are located all over the world, also in Germany, i.e. in Berlin, Bremen, Dresden, Dusseldorf, Hamburg, Hannover, Munich and Münster.

Investments by Polish companies in Germany are not only limited to the acquisition of existing companies. New companies or production plants called greenfield are being established. Below a table including a number of Polish companies is presented.

Table 4. Greenfield projects of major Polish companies greenfield

\begin{tabular}{|c|c|c|c|}
\hline Year of establishment & Investing company & Headquarters & Industry sector \\
\hline 2013 & CCC & Bavaria & Textiles \\
\hline 2013 & ComArch & Saxony & IKT \& Software \\
\hline 2013 & Matplast & Bavaria & Tworzywa sztuczne \\
\hline 2012 & TTcomm & Baden-Wuerttemberg & IKT \& Software \\
\hline 2012 & ZPAS Group & Saxony & IKT \& Software \\
\hline
\end{tabular}

Source: www.gtai.de, 30.01.2019

\section{FDI OF POLISH COMPANIES IN GERMANY}

The Federal Republic of Germany is an increasingly popular investment market for Polish companies. It is worth noting the annual surveys conducted by the Central Statistical Office (GUS). The first research on the activity of Polish entities owning foreign ones was conducted for the year 2008 . 
Starting from 2008, the annual growth of entities based in Poland with foreign entities is visible. The size structure of parent companies and their subsidiaries is presented below:

Table 5. Entities with headquarters in Poland and their foreign subsidiaries in 2010-2016

\begin{tabular}{|l|c|c|c|c|c|c|c|}
\hline & 2010 & 2011 & 2012 & 2013 & 2014 & 2015 & 2016 \\
\hline $\begin{array}{l}\text { Entities with } \\
\text { headquarters } \\
\text { in Poland }\end{array}$ & 1380 & 1438 & 1373 & 1520 & 1562 & 1667 & 1716 \\
\hline $\begin{array}{l}\text { Foreign sub- } \\
\text { sidiaries }\end{array}$ & 2853 & 3060 & 3084 & 3252 & 3532 & 3890 & 3897 \\
\hline
\end{tabular}

Source: own studies based on data from the Central Statistical Office, Department of Information

It should be noted that with the exception of 2012, the growth of entities with headquarters based in Poland has been observed in the years 2010-2016. In the case of foreign entities, annual growth of this form of foreign investment is visible. Analyzing the number of reporting entities and their foreign units according to the CSO from 2016, it should be emphasized that the largest number of enterprises had their headquarters located in the Mazowieckie Voivodeship (there were 474 entities which had 1106 foreign units located abroad), Śląskie (there were 227 entities which had 331 foreign units located abroad) and Wielkopolskie (157 entities had 358 foreign units located abroad. The provinces in which the fewest reporting entities were located were Warmińsko-Mazurskie and Podlaskie (Central Statistical Office, Department of Information).

It is also worth noting the share of entities owning foreign subsidiaries according to the Polish Activity Classification (PKD) from 2016. (Figure 3).

Figure 3. The share of entities owning foreign subsidiaries according to the Polish Activity Classification (PKD) from 2016.
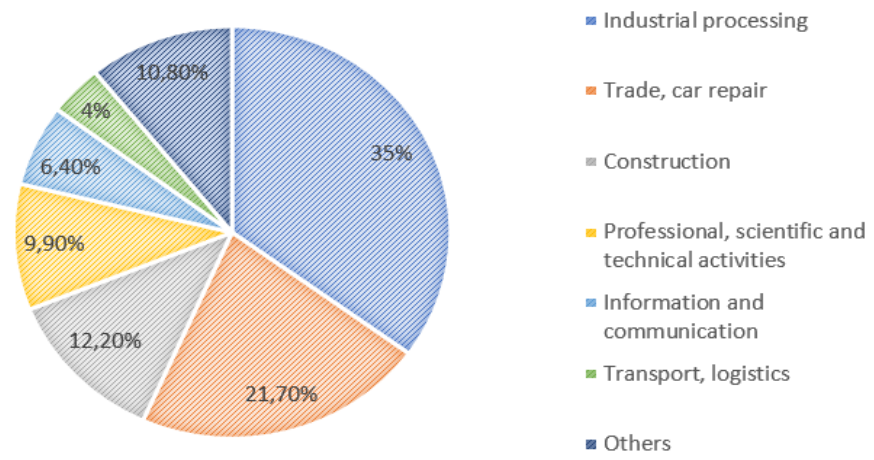

Source: Central Statistical Office, Department of Information 
In 2016, it can be observed that the share of entities with foreign entities was the highest in the section of industrial processing (which accounts for $35 \%$ of the total share of entities with foreign entities, while in 2015 the share was $31.4 \%$ ) and trade (which accounts for $21.7 \%$, in 2015 the share was $20.7 \%$ ) or construction (which accounts for $12.2 \%$ ).

The location of foreign entities is also particularly important. Due to the geographical distance, most of these units are located in Europe (Table 6).

Table 6. The number of foreign subsidiaries according to continents in 2010-2016

\begin{tabular}{|l|c|c|c|c|c|c|c|}
\hline \multirow{2}{*}{ Continents } & \multicolumn{7}{|c|}{ Years } \\
\cline { 2 - 8 } & 2010 & 2011 & 2012 & 2013 & 2014 & 2015 & 2016 \\
\hline Total & 2853 & 3060 & 3084 & 3252 & 3532 & 3890 & 3897 \\
\hline Europe & 2475 & 2666 & 2643 & 2792 & 2926 & 3228 & 3217 \\
\hline $\begin{array}{l}\text { Other conti- } \\
\text { nents }\end{array}$ & 378 & 394 & 441 & 460 & 606 & 662 & 680 \\
\hline
\end{tabular}

Source: own studies based on data from the Central Statistical Office, Department of Information

The annual growth of foreign units of Polish companies in Europe is observed. Their number in 2016, compared to 2010, increased by almost $30 \%$. Also on other continents, the number of foreign units is growing every year. In 2016, there were as many as 680 foreign units, which is almost $80 \%$ more than in 2010 . Attention should also be paid to the number of foreign units in individual countries bordering Poland (Table 7).

Table 7. Number of foreign subsidiaries of selected countries in 2015 and 2016

\begin{tabular}{|l|c|c|}
\hline Country & 2015 & 2016 \\
\hline Belarus & 89 & 84 \\
\hline The Czech Republic & 301 & 289 \\
\hline Germany & 552 & 562 \\
\hline Russia & 271 & 245 \\
\hline Slovakia & 165 & 164 \\
\hline Ukraine & 331 & 288 \\
\hline
\end{tabular}

Source: own studies based on data from the Central Statistical Office, Department of Information

In 2016, most foreign units were located in Germany, the Czech Republic, Ukraine and Russia. In 2016, 1744 foreign units were located in all seven countries bordering Poland, which is a 1\% decrease compared to 2015. 
Figure 4. Number of subsidiaries in selected European countries

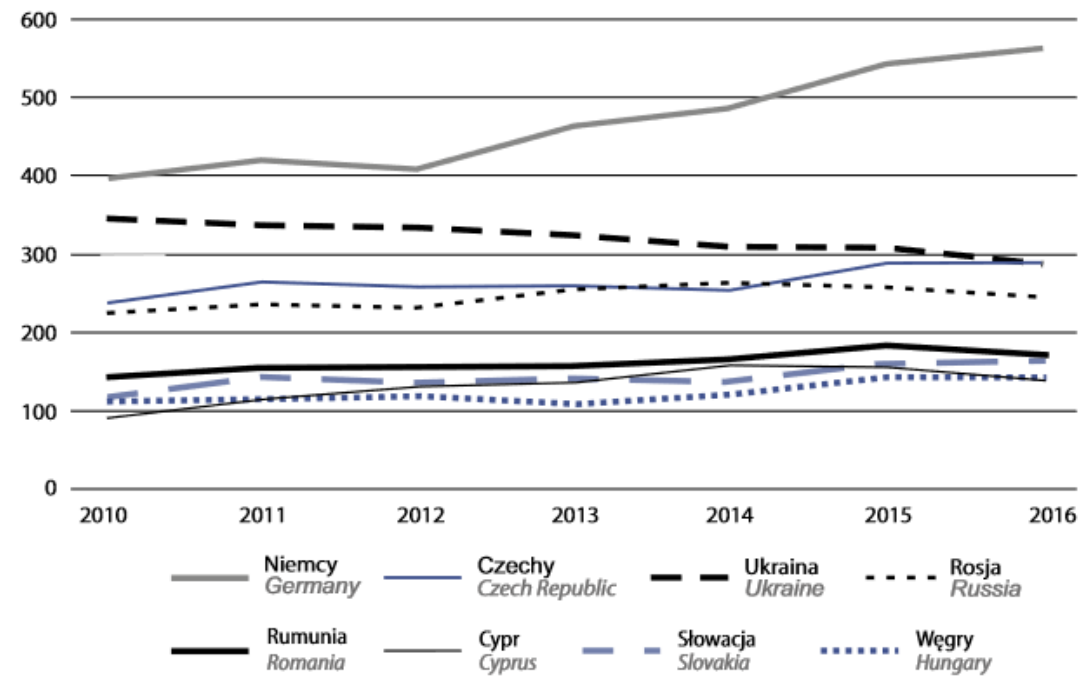

Source: Central Statistical Office, Department of Information

When analyzing the number of foreign units in selected European countries, one should pay attention to their number in Germany. Since 2010, a gradual growth of foreign units has been observed. Despite a slight downward trend, a significant increase was visible in 2012, e.g. in comparison with other neighbouring countries of Poland (in Ukraine, for example, there is an annual decrease in this form of internationalization). The number of foreign units of Polish enterprises in Germany between 2010 and 2016 is presented below (Table 8).

Table 8. Number of foreign subsidiaries of Polish companies in Germany in 2010-2016

\begin{tabular}{|c|c|c|c|c|c|c|c|}
\hline \multirow{2}{*}{ Country } & \multicolumn{7}{|c|}{ Years } \\
\cline { 2 - 8 } & 2010 & 2011 & 2012 & 2013 & 2014 & 2015 & 2016 \\
\hline \multirow{2}{*}{ Germany } & 400 & 427 & 412 & 469 & 495 & 552 & 562 \\
\cline { 2 - 8 } & $100 \%{ }^{1}$ & $106,75 \%$ & $103 \%$ & $117,25 \%$ & $123,75 \%$ & $138 \%$ & $140,5 \%$ \\
\hline
\end{tabular}

Source: own studies based on data from the Central Statistical Office, Department of Information

In 2010, there were 400 foreign units in Germany. In 2011, the number of subsidiaries increased by 27 compared to 2010, with a slight decrease of about 3.75 percent in 2012 . The following years were marked by continuous growth. Compared to 2010, the growth of these forms of internationalization reached almost $41 \%$, which is 162 companies. 
Apart from the number of foreign units of Polish companies, attention should be paid to other data concerning, for example, the number of employees, total revenues or expenditures on tangible fixed assets (Table 9).

Table 9. Selected data on foreign units located in Germany in 2015-2016

\begin{tabular}{|l|c|l|l|l|l|}
\hline \multirow{2}{*}{$\begin{array}{l}\text { Germany } \\
\text { ployees }\end{array}$} & & Total income & Export & Import & $\begin{array}{l}\text { Spendings of } \\
\text { tangible fixed } \\
\text { assets }\end{array}$ \\
\cline { 2 - 6 } & & \multicolumn{5}{|c|}{ w mIn zł } \\
\hline 2015 & 27.864 & $39.197,0$ & $4.570,5$ & $5.468,3$ & 383,0 \\
\hline 2016 & 32.778 & $39.507,5$ & $3.039,7$ & $5.407,8$ & 407,3 \\
\hline
\end{tabular}

Source: own studies based on data from the Central Statistical Office, Department of Information

An analysis of the employment structure in foreign entities in Germany shows an upward trend. The number of employees in 2016 increased by about $18 \%$ compared to 2015 and was the highest among all the countries neighbouring Poland where foreign entities were located.

Taking into account the location of the surveyed foreign units, also the highest sales revenues among the countries neighboring Poland were achieved by foreign units located in Germany (Figure. 4). In comparison to 2015, in 2016, there was a slight increase in the sales revenue, yet only by about $1 \%$.

Figure 5. Value of net income from sales revenues of goods and materials per a single foreign unit for selected countries of a foreign unit's headquarters in 2010-2016

\section{틀 2010 틀 2011 틀 2012 틀 2013 틀 2014 틀 2015 틀 2016}

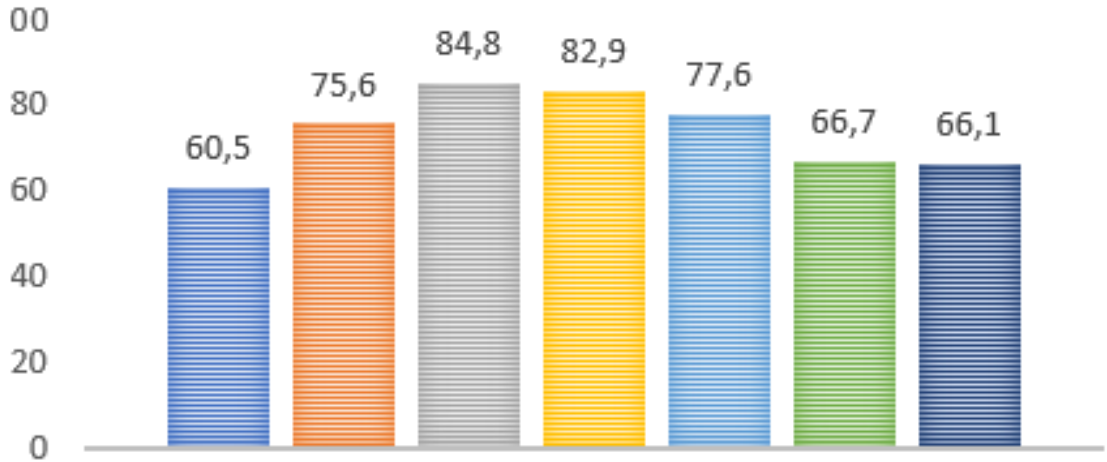

w mln zł

Source: own studies based on data from the Central Statistical Office, Department of Information 
When analyzing the value of net revenues per one foreign entity, a gradual decrease since 2012 is visible. It can be seen that the increase in the number of foreign entities does not increase the value of net revenues per one foreign entity. This state of affairs is a result of decreasing net revenues.

As far as expenditures on tangible fixed assets are concerned, they were valued in 2015 at 383 million PLN. In 2016 this valuation increased to 407.3 million PLN. In 2015-2016, foreign entities recorded a negative balance of payments, i.e. the volume of imports exceeded exports.

In order to verify the research hypothesis, partial correlation coefficients were calculated, which will allow to determine to what extent a given economic characteristic (total revenues, number of employees, export, import, expenditure on tangible fixed assets) affect the number of foreign units, but only that part of it which was not explained by other analyzed variables.

The calculated partial correlation coefficients indicate a large, positive correlation between the number of foreign units and all of the analyzed economic characteristics. A positive correlation sign means that an increase in the value of individual characteristics will increase the number of foreign units.

\section{SUMMARY}

Globalization and trade liberalization of trade have had significant impact on the development of foreign direct investment. Polish companies, wishing to increase their revenues and acquire new customers, make decisions to get involved in foreign expansion. The aim of these considerations was to analyze the foreign direct investments of Polish companies in the Federal Republic of Germany. The research hypothesis was also verified. It should be assumed that an increase in the value of the individual characteristics will increase the number of foreign units.

In the author's opinion, these issues are an important voice in the discussion and fit into the current topic, but require further in-depth analysis.

\section{BIBLIOGRAPHY}

Alisch K., Winter W., Arentzen U. (2004), Gabler Wirtschaftslexikon-Classic Edition: Die ganze Welt der Wirtschaft: Betriebswirtschaft, Volkswirtschaft, Recht und Steuern, 4 Bde., Wydawnictwo Gabler, Wiesbaden.

Ausländische Direktinvestitionen in Deutschland - Potenzale Polen, www.gtai.de [20.09.2019].

Bank Polski, AHK, CMS. Polskie firmy na niemieckim rynku-wyzwania, szanse, możliwości (2016). www.media.pkobp.pl [20.08.2019].

Barłożewski K. (2017), Wpływ ekspansji zagranicznej na efektywność przedsiębiorstw. Warsaw: published by. C.H. Beck Publishing House

Czech-Winkelmann S. (2008), Exportieren, kooperieren oder Direktinvestitionen - alternative Marktstrategien, [w:] Czech-Winkelmann S., Kopsch A. (eds.), Handbuch International Business. Strategie, Praxis, Fallbeispiele, Erich Schmidt Verlag, Berlin. 
Deutscher Außenhandel - Export und Import im Zeichen der Globalisierung, www.destatis.de [20.11.2019].

Central Statistical Office (2012, 2013, 2014, 2015, 2016, 2017, 2018). Działalność podmiotów posiadających jednostki zagraniczne, www.stat.gov.pl [01.01.2020].

KfW Bankengruppe (2011). Die zunehmende globale Bedeutung der Schwellenländer, www.kfw. de [20.09.2019].

Kuźmińska A., Mirecka E., Szeląg T. (2010), Międzynarodowe przepływy czynników produkcji. [in:] Rymarczyk J. (eds.), Międzynarodowe Stosunki Gospodarcze, PWE, Warsaw.

Polish-German Chamber of Industry and Trade (AHK) (2018), Polskie przedsiębiorstwa w Niemczech: perspektywy działalności w Niemczech sa jednoznacznie dobre, www.ahk. $\mathrm{pl}$ [20.09.2019].

Polish-German Chamber of Industry and Trade (AHK), www.ahk.pl [20.09.2019].

Integrated Report of ORLEN Group 2017, www.orlen.pl [20.09.2019].

Rogaczewski R. (2017), Wybrane aspekty handlu międzynarodowego na przykładzie Polski i Niemiec, [in:] Zastempowski M. (eds.), Acta Universitatis Nicolai Copernici (2) 87-100.

Rymarczyk J. (2012), Logistyka w procesach zarządzania łańcuchem dostaw korporacji transnarodowych, [in:] Gołembska E., Bentyn B. (eds.), Logistyka międzynarodowa wyzwaniem dla gospodarki światowej. Zeszyty Naukowe 2012 (224), UE Publishing House, Poznań.

Wyżnikiewicz B. (2014), Wspótpraca gospodarcza Polska - Niemcy, Institute of Market Economy Research, Warsaw.

Foreign direct investments on Poland in 2017, www.nbp.pl [20.09.2019]. 
